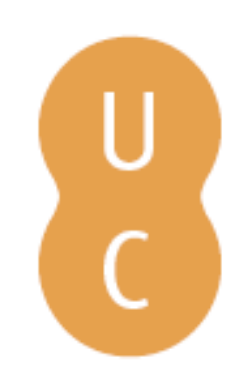

\title{
nombalina
}

\section{How to imagine community without property}

Autor(es): $\quad$ Armstrong, Nancy; Tennenhouse, Leonard

Publicado por: Imprensa da Universidade de Coimbra

URL

persistente: URI:http://hdl.handle.net/10316.2/42310

DOI: $\quad$ DOl:https://doi.org./10.14195/978-989-26-1308-6_2

Accessed : $\quad$ 26-Apr-2023 16:00:30

A navegação consulta e descarregamento dos títulos inseridos nas Bibliotecas Digitais UC Digitalis, UC Pombalina e UC Impactum, pressupõem a aceitação plena e sem reservas dos Termos e Condições de Uso destas Bibliotecas Digitais, disponíveis em https://digitalis.uc.pt/pt-pt/termos.

Conforme exposto nos referidos Termos e Condições de Uso, o descarregamento de títulos de acesso restrito requer uma licença válida de autorização devendo o utilizador aceder ao(s) documento(s) a partir de um endereço de IP da instituição detentora da supramencionada licença.

Ao utilizador é apenas permitido o descarregamento para uso pessoal, pelo que o emprego do(s) título(s) descarregado(s) para outro fim, designadamente comercial, carece de autorização do respetivo autor ou editor da obra.

Na medida em que todas as obras da UC Digitalis se encontram protegidas pelo Código do Direito de Autor e Direitos Conexos e demais legislação aplicável, toda a cópia, parcial ou total, deste documento, nos casos em que é legalmente admitida, deverá conter ou fazer-se acompanhar por este aviso.

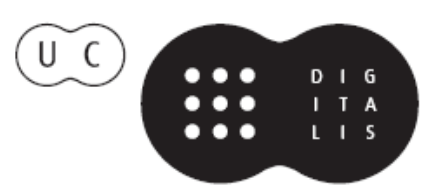





\section{HOW TO IMA G I E COMMUNITY WITHOUT PROPERTY ${ }^{1}$}

Nancy Armstrong and Leonard Tennenhouse

Resumo: Este artigo baseia-se no pressuposto de que os primeiros romancistas americanos sentiam que a circulação internacional de pessoas e bens estava a corroer a fantasia de um isolamento que um mundo apoiado na propriedade parecera garantir. É possível retirar esta conclusão a partir da grande percentagem de romances que sistematicamente revertem a lógica da propriedade segundo Kant, Malthus e outros intelectuais europeus do mesmo período. Ao desmantelar a fantasia da propriedade, os romances dos primeiros tempos da República estão claramente a mudar a forma do romance para testar uma base alternativa das relações sociais. O que procuravam? Que objetivo comum os incitava a criar romances que dispersavam pessoas e bens, assim desafiando a fantasia que a Europa tinha da América como uma terra virgem disponível para ser apropriada? Se tivermos em conta a sua proliferação nos E.U.A. durante o período de 1789-1820, estes romances, pelas redes que constroem, parecem corresponder à necessi-

${ }^{1}$ In deep appreciation of the years spent in Portugal enjoying the intellectual generosity of Maria Irene Ramalho de Sousa Santos. 
dade dessa alternativa por parte de um público amplo e ele próprio disperso.

Palavras-chave: romance; rede; propriedade; primeiras décadas da América; comunidade imaginada.

\begin{abstract}
We assume that early American novelists felt that the international circulation of persons and property was eroding the fantasy of self-enclosure that a world made of property promised to guarantee. This is what one may gather from the sheer percentage of these novels that systematically reversed the logic of property shared by Kant, Malthus, and any number of European intellectuals of the same period. By so dismantling the fantasy of property, the novels of the early republic make it only too clear they were changing the novel form to try out an alternative basis for social relationships. What were they after? What common sense of purpose prompted them to fashion novels that so dispersed persons and their property as to challenge Europe's fantasy of America as a wasteland awaiting appropriation? Judging by its proliferation in the United States during the period from 1789 through the 1820s, the network novel addressed a felt need on the part of a diverse and scattered readership to imagine such an alternative.
\end{abstract}

Keywords: Novels; Network; Property; Early American; Imagined community.

The early American novel invariably begins by scattering the contents of some well-established social unit - generally a version of the family, but sometimes a local community, a congregation, or members of a craft or profession. The early American novel achieves 
its form as it strips all such materials of their status as property and provides them with new footing in an Atlantic World. That it does so appears at first glance to bear out Locke's fantasy of America as the best place in that world to assemble a little commonwealth of one's own, something like Robinson Crusoe's island sanctuary, a social unit complete with its sovereign exceptions, excluded populations, and internal hierarchies. But the early American novel fails - and fails conspicuously - to produce such an enclosure. Where the meandering of the European picaresque exposes the abuses that maintain the various levels of a society based on hereditary privilege, the meandering narrative of early American fiction opens up that relatively closed system and puts its elements into motion. Once this happens, it no longer makes sense to think of social interactions as the formation of community. We are far better off understanding community as a process that tries out different ways of making community.

In response to recent multidisciplinary scholarship concerning networks and networking, literary criticism and theory are also making use of terms that describe the formation of a network as a "flow" of bodies, goods, and information. Because this metaphor so readily lends itself to a biopolitical reading, or perhaps because of the sheer number of early American novels that experiment with shipboard communities and migrant people, we were initially tempted to think of social relationships in these novels as a "flow." For the purpose at hand, however, we found the fluidity it implies too likely to obscure the collisions and joints that occur as characters move with or against one another in a way that prevents us from asking what moves them. Then there's the more obvious problem that "flow" creates the illusion that the relationships formulated by early American fiction can be read as an allegory for relationships that people form when they are on the move - an allegory, if you will, for the formation of "a nation of immigrants." or "a melting pot." 
To do so, however, is to see homogeneity where actually there was heterogeneity. The concept of "flow" obscures not only the stop-andstart character of migration patterns. It also obscures the fact that at any given time in recorded history, the majority of the world's population has been relatively sedentary. ${ }^{2}$ Eighteenth-century America was no exception. To read the disjointed, multiple, and contingent narratives of early American fiction as allegories for a "flow" of populations therefore amounts to ignoring what we regard as "the event" of these novels, namely, the transformation of what Georg Lukàcs calls a "biographical" form into a network that circulates people, goods, and information among disparate communities to form a population (77). This transformation within and of the novel form does not refer outward to a political transformation occurring elsewhere - or if it does, that reference provides the occasion for an alteration of the novel's inner form that also alters its relation to the world of history. ${ }^{3}$

In preferring the semiotic potential of the term "dispersal" over the term "flow," we are keenly aware that "dispersal" is no less a borrowed term and carries a certain amount of cultural baggage that it shares with "diaspora," thus to the considerable work in the field of diaspora studies. ${ }^{4}$ "Diaspora," as we see it, implies a group that imagines itself bound to a vanished origin and so counts on some "inalienable possession" to differentiate its members from all other

\footnotetext{
${ }^{2}$ We are indebted to Khachig Tölölyan for alerting us to the fact that although "flow" is often used to describe the movement of diasporic peoples, the metaphor tends to be misleading; it does not acknowledge the blockages and obstacles that often prevent the regular and continuous flow of electricity, water, and peoples. Nor does it account for the fact that most people are relatively sedentary ("The Contemporary Discourses of Diaspora," 654).

3 For a more extensive argument to this effect that takes aim at Benedict Anderson's formal description of the national community that novels imagine, see Armstrong and Tennenhouse.

${ }^{4}$ For an account of the term "diaspora" in relation to British North America, see Tennenhouse, The Importance of Feeling English, 9-13.
} 
members of a population, no matter how frequently and widely that group has been deterritorialized. 5 By contrast, the early American protagonist characteristically undergoes a sequence of divestments that strips away the protocols that would attach that individual to such a group and then scatters the features and practices that indicate such group affiliation. "Dispersal" comes closest to describing the scattering of populations and their properties that allows early American novels to try out new social formations. Despite the fact that they were published in small editions that reached chiefly local readerships, across the board these novels showed not only where the social model implied by British fiction broke down, but also how its pieces could be reassembled without suppressing the incompatibilities among them. ${ }^{6}$

\section{The besieged enclosure}

By the end of the eighteenth century, Europe was fixated on this problem with an eye toward controlling the dispersal of people

\footnotetext{
5 In Inalienable Possessions, Annette B. Weiner explains that no matter how much of their culture a group of people gives up, they must hang onto the one feature or possession that "is intrinsic or ineffable" to the identity of the person, family, or tribe and necessary to that identity remaining intact (6-7).

${ }^{6}$ As Trish Loughran notes, "Royal Tyler lived in New Hampshire and so published in New Hampshire - with the consequence that readers in Boston who might have wanted a book like Tyler's Algerine Captive could not get their hands on it" (21). Joseph Dennie, Tyler's friend and collaborator, explains the problem: "Your novel has been examined by the few and approved. It is however extremely difficult for the Bostonians to supply themselves with a book that slumbers in a stall at Walpole [New Hampshire], supposed by the latest and most accurate advertisements, to be situated 400 miles north of their meridian," The Letters of Joseph Denie 1768-1812, ed. Laura G. Pedder (Orono: University of Maine Press, 1936), 165, August 30, 1797. See also William Chavrat, Literary Publishing in America, 1790-1850 (Amherst: University of Massachusetts Press, 1959), 25-6. See also James N. Green, "The Rise of Book Publishing," ed. Robert A. Gross and Mary Kelley, Vol. 2. A History of the Book in America (Chapel Hill: University of North Carolina Press, 2010), 75-127.
} 
and property. ${ }^{7}$ Writing in the wake of the French and American revolutions and the moment of England's industrial takeoff, Immanuel Kant and Thomas Malthus could not contemplate the erosion of national boundaries without recalling the former settler colonies in North America and the experiment in nationhood that was currently underway there. At the moment in history still thought to have instigated the greatest growth spurt of European nationalism, we find these two influential thinkers regarding the nation as an endangered species. Despite their conflicting notions of the ultimate cause for the increasing permeability of territorial boundaries, both thought of the nation in terms of enclosure, and they proposed defensive strategies for preserving it in the face of hostile forces. To do so, moreover, each found it necessary to grant the inevitability of international commerce and devised a way of balancing the self-containment of persons, property, and local practices over and against the movement of people, goods, and information. Thus, despite the imperial expansion of European nations into other regions of the globe, and although Kant and Malthus approached the problem from quite different theoretical positions, both equated the nation with property and the nation's laws, with protecting that property.

Immanuel Kant's "Perpetual Peace: A Philosophical Sketch" (1795) is his signature attempt to resolve the conflict between the free movement of people and commerce and the sanctity of boundaries that identified one's property in oneself, one's labor, one's household and lands, and one's community or ethnos. As an alternative to promoting the one at the expense of the other, Kant proposed a "law of hospitality" to guarantee the integrity of a person, kin group, and

7 As Charlotte Sussman explains, throughout the eighteenth century "population" usually meant the opposite of "depopulation," which was of greater concern until Malthus shifted the emphasis entirely. We thank her for sharing with us the manuscript for her forthcoming book, "Peopling the World: Imagining the Population from Milton to Malthus." 
nation in an age when Europe was becoming increasingly dependent on international commerce. Given that "the natural state is one of war" (112), as he put it, echoing Hobbes, no amount of hospitality would actually put an end to conflict, but he thought that requiring each individual to pledge security to his neighbor could go a ways toward mitigating the natural hostility between one individual and another (111). On the assumption that republican states already had laws on the books protecting the persons and property of their citizens, what was needed, Kant argued, was a "law of hospitality" that would ensure "the right of an alien stranger not to be treated as an enemy upon his arrival in another country" (118).

Derived from the Latin "hospes," meaning "host," "guest," or "stranger," which comes in turn from "hostis," meaning "stranger" or "enemy," "hospitality" is one of those fabled primal words whose meaning, like that of the "uncanny" itself, can easily turn into its opposite. From the previous quote, it is not difficult to see how Kant intended to exploit this reversibility to transform a concept that promoted tribal loyalty, the trading of women, and a gift economy into a concept that would promote the interests of a cosmopolitan group of property owners. To do so, he simply extrapolated the logic of property to the level of the nation, where he used it to insist that each nation with laws that protected property rights would agree not to violate the sovereign rights of other nations. The principle of hospitality would not only grant such rights to individuals but also entitle them to travel safely throughout the world and associate with other people. It is not in softening the intolerance of the host so much as in ensuring the visitor's right of association that Kant seizes on the inherent reversibility of the term "hospitality."

"By virtue of their common ownership of the earth's surface," he reasons, people "cannot scatter themselves infinitely, but must finally tolerate living in close proximity" (118). To guarantee what 
he initially describes as the positive "right of association," Kant needs a means of extending the security of one's home to the entire world before individuals can enter into "peaceable relations with each other." Before civilized individuals can safely move through the world, however, the right to association must be transformed into a negative right that curbs "the inhospitable conduct of civilized nations, especially commercial ones" (119). The sense of entitlement to appropriate the resources and people of the places that the Europeans visited is, in Kant's view, what makes the behavior of otherwise law-abiding individuals resemble "the inhospitableness that coastal dwellers show...by robbing ships in neighboring seas and by making slaves of stranded seafarers or of desert dwellers." They are bandits "who regard their proximity to nomadic peoples as giving them a right to plunder" (118).

Was he intent on showing that all men exist in a natural state of warfare when Kant pointed to members of the civilized nations as those most likely to seize the persons and property of people and resources not so protected by property law? Or was he questioning whether or not the immunity provided by property was sufficient to create a foundation for hospitality? As he put it, "[T]he injustice that [civilized men] display to foreign peoples... (which is the same as conquering them) is terrifying. When discovered, America, the lands inhabited by the blacks, the Spice Islands, the Cape, etc., were regarded as lands belonging to no one because their inhabitants were counted for nothing" (119). Kant offers this evidence to support his belief that nothing short of the universal protection of property rights will counteract the natural law of hostility. But inasmuch as he also believed that America belonged in common to its inhabitants rather than to individual property owners, it could not be considered "waste." Nor, then, were resources there for the taking. At this point in his career, Kant comes close to admitting that his law of hospitality applied only to societies with laws guaranteeing property 
rights. Hospitality would not protect those who belonged to societies organized otherwise.

Published in 1798, only three years after Kant's proposal for achieving "perpetual peace," Thomas Malthus's An Essay on The Principle of Population argued that neither law nor human reason could bring about peace that did not take into account the alternate cause of human hostility. For Malthus, the cause not only of war but also of famine and disease could be boiled down to the relationship between two immutable principles: "First, That food is necessary to the existence of man. Secondly, That the passion between the two sexes is necessary" and cannot be effectively curtailed on a mass basis (19). The relationship between these two laws produced what he called "the principle of population" - namely, that "population, when unchecked, increases in a geometric ratio" while "subsistence increases only in arithmetical ratio" - determines that population growth will either be checked by famine or disease or bring people to war over the resources necessary for their survival (19). A significant imbalance between people and food will, in Malthus's view, ultimately make men cruel. ${ }^{8}$

That neither property law nor individual reason are sufficient to deal with the problem becomes especially clear as Malthus compares the United States to England in terms of population growth, a comparison he uses to counter William Godwin's late Enlightenment belief that human reason would eventually control man's physical passions and instincts. According to Malthus's sources, the population in British America grew from 21, 200 in 1643 to an estimated three

${ }^{8}$ With the French Revolution undoubtedly at the back of his mind, Malthus argues that even Europe has experienced the apocalyptic consequences "arising from the want of subsistence... Want was the goad that drove the Scythian shepherds from their native haunts, like so many famished wolves in search of prey. Set in motion by the all-powerful cause, clouds of barbarians seemed to collect from all points of the northern hemisphere. Gathering fresh darkness and terror as they rolled on..." (28). 
million before the War for Independence. England - having recovered from losses incurred through emigration, just as it had from the ravages of the London Plague - experienced nothing like that surge in population, a discrepancy that Malthus attributed to a combination of factors: that workers had not begun to amass in North American cities; that several states had abolished the inheritance of land; and that Pennsylvania even passed a law granting uncultivated land to anyone who agreed to cultivate it. Here, Malthus's biopolitical analysis approached Kant's legal reasoning in that both took as given that a nation is just so much potential property. Bent on arguing that the passion between the sexes has remained nearly the same across time and geography, Malthus held their respective food supplies responsible for the discrepancy between the rates of population growth in England and North America, where considerably more land was available for this purpose. ${ }^{9}$

A notably tortured simile makes it clear why, contrary to commonsense, Malthus would see such an increase in food production as a problem and not a solution to the problem of population. In order to grow an unnaturally large flower by adding "richer mould" to the soil, he explains, an "enterprising florist" might "burst the calyx and destroy at once its symmetry." The same holds for political change. "In a similar manner," Malthus contends,

the forcing manure used to bring about the French revolution, and to give a greater freedom to the human mind, has burst the restraining bond of all society... And however large the separate petals have grown, however strangely or even beautifully marked,

${ }^{9}$ Malthus objected to industrial labor and believed the nation was better off "if the wealth that supported two hundred thousand men while they were producing silks and laces would have been more usefully employed in supporting them while they were producing the additional quantity of food," An Essay on the Principle of Population, 107. 
the whole is at present a loose, deformed, and disjointed mass, without union, symmetry, or harmony of colouring. (91)

If we carry it over to North America, as Malthus invites us to do, this figure of a disfigured flower yields two conclusions. First, that a more even distribution of resources (through emigration, as well as the relaxation of property laws) not only disrupts the proportionate distribution of resources that maintains social relations within the civilized nations, but ultimately leads to yet more uneven distribution of the resources. Secondly, the botched experiment with natural growth, if put into human practice, yields a nation that is a "loose, deformed, and disjointed mass, without symmetry, or harmony of colouring," a situation that clearly applies to the social disorder in the United States as well as in post-Revolutionary France. Thus despite the fact that Malthus's argument, as he said, "considered chiefly the mass of mankind and not individual instances" (91), he nevertheless shared Kant's assumption that a reasonably stable social order is bounded, homogeneous, relatively harmonious, and legally designed to maintain the correct balance between owners and laborers. In that it erodes boundaries, encourages heterogeneity, and disrupts the ratio of population growth to food production, international commerce will, like the "enterprising florist," dismantle the body it wants to enhance.

Malthus, much like Kant, confronted a body politic capable of spreading beyond the boundaries of self and nation that guaranteed his own identity as author and intellectual, and he envisions this body in monstrous terms, as a violation of the very principle of form. Early American novelists understood - at least as well as any European - that the international circulation of persons and property violated the fantasy of self-enclosure that owning property seemed to guarantee. As a result, the early American novel systematically reverses the logic of property shared by Kant, Malthus, and any 
number of other European intellectuals. By so dismantling the fantasy of property, novelists made it clear that their purpose, by contrast, was to formulate alternative possibilities. They had no intention of using the novel to reproduce an unworkable model. For this reason, and not by virtue of collective ineptitude of these early novelists, the post-World-War II scholars of American literary tradition would not find a novelist prior to Cooper who measured up to the British standard of form as the means of producing an ethnic synthesis and enclosed habitus.

\section{Unsettling Form}

The term "dispersal" is not only basic to the formation of a system of social relationships that might otherwise seem continuous and all but self-explanatory, "dispersal" is also the first step in understanding that system. Rather than think of this formation as either a flow (as in a journey or voyage) or a container (as in home or settlement), the term "dispersal" invites us to consider how a network forms a social world while not becoming either one. The story of the early American protagonist usually proceeds by stripping away whatever features attach him or her to some group. This protagonist has no interest in securing his property against appropriation by another group. Nor can we say that he or she has his own wife and her own husband and children and belongs in turn to them; the trading of women among men of property makes no more sense than lines of inheritance that would keep that property within the kin group.

Then perhaps it is wayward sexual passion that causes the dispersal that sets a narrative in motion. When Arthur Mervyn's widowed father succumbs to the wiles of his milkmaid, the relationship sets off a chain reaction, and Mervyn must start from scratch to form a character. When a man swindles her father, Constantia, the 
protagonist of Ormond (1799) loses everything but her good name and becomes vulnerable to the advances of the libertine Ormond who would degrade its meaning. In The Power of Sympathy, Harrington Senior's seduction of Maria Fawcet leads to his son's suicide upon learning that the woman he loves is actually his half-sister. Dispersal is not only the fate of every family in which a young woman is seduced by a libertine. Such novels as Sarah Woods's Dorval (1805) and Isaac Mitchell's The Asylum (1811) insist that a downturn in economic fortune can as easily break up a family and send its members out in the world either to perish or to find a livelihood. But no matter how many times they repeat this pattern, we will insist, these novels do not anticipate Malthus's case for the persistence of sexual passion, any more than they do Kant's claim that human beings are naturally inclined to exploit one another.

When we consider how often sheer curiosity is offered as the reason for dispersal, sexual passion and competitive aggression begin to lose their explanatory punch. Captain Farrago begins his travels in Modern Chivalry simply "to see how things were going on here and there and to observe human nature" (Brackenridge 4); it seems appropriate to think of them as symptoms of a more basic drive on the part of human beings to combine freely and disperse widely. The American picaresque often begins in a community bound by practices that maintain its homogeneity over time, a standard that calls attention to the extraordinary social and cultural diversity the traveler encounters in the new United States. That the place of origin need not be European, so long as it is characterized by enforced homogeneity, is demonstrated by a minor surge in Algerian narrators during the period of the early republic. Peter Markoe's The Algerine Spy in Pennsylvania (1787) is an epistolary novel consisting of letters largely by Mehemet, an Algerian official. The tyrannical Osman, Dey of Algiers, has dispatched Mehemet to the United States to discover the political climate of the new nation. Disguised as a 
Frenchman, he travels first to Gibraltar and there learns his first lesson in tolerance, namely, that Spain's decision to cast out the Moors "weakened Spain at least as much as the banishment of the Protestants reduced the resources of France in the reign of Louis the XVIth" (Markoe 14).

Mehemet's second lesson in tolerance reinforces the first in even more personal terms. Rumored to have become a Christian, he receives notice that "[b]y order of the Dey, thy lands, house, furniture and slaves (two excepted) are confiscated to the state" (112). Should Mehemet be found in "the territories of Algiers," his correspondent warns, "thy life will be forfeit" (113). No more bound to respect his right to property than Spain or France, Algeria expresses its nationalism by means of religious intolerance. Pennsylvania, by contrast, offers both Mehemet and his estranged wife the land on which to start up separate households. Pennsylvania, he writes, "has promised to succor and protect the unhappy, that fly to thee for refuge." Mehemet cites American tolerance as the reason why he thinks of himself as "formerly a Mahometan." He has renounced, this suggests, only what he now understands as Islamic intolerance in order to enjoy, "in the evening of his days, the united blessings of FREEDOM and CHRISTIANITY" (125). Christianity becomes a code word for tolerance and variability in this novel.

What role does property play in this fantasy of America as a place where an Algerian spy can settle down? As he concludes his story, Mahemet certainly makes it seem as if he and his wife have not only converted to the dominant religion but also acquired property. As he describes it, owning property does not carry out the defensive strategy of removing oneself from community. To the contrary, because Mehemet and his wife can own property, the implication is that anyone can. By becoming a Christian, he defines himself as someone who could not be tolerated in Algeria, someone who consequently rejects intolerance. When Mehemet and his wife decide 
to settle in Pennsylvania, however, his story appears to contradict our claim that his is a story of dispersal, or unsettlement novel. But if we recall that his marriage has dissolved, then it becomes clear that their decision to settle in Pennsylvania does not land them in a domestic sanctuary (in the manner of the English Joseph Andrews) but allows them to circulate within a community that is the more heterogeneous for their doing so. Having begun as if aiming to settle, this novel holds true to the pattern: it disperses anything like a community should it begin to form. In this way, it reverses the process by which an individual accumulates property in himself and produce a narrative that moves through a sequence of dispersals.

Narrated by a French traveler, Samuel Lorenzo Knapp's Extracts from the Journals of Marshal Soult (1817) finds much to admire in the United States. His journal entries conclude as he is about to leave New England for the American South, which he expects to find even more congenial to his habits and sensibility. Before he can do so, however, Knapp himself decided against having a Frenchman as narrator and more or less rewrote the entire account. Published as Extracts from a Journal of Travels in North America (1818), the second version of this fictional journal of travel in the United States surveys the nation from the perspective of an Algerian spy who has come to America to assess the possibility of converting its people to Islam. If in the sophisticated world of the Boston Brahmins, Ali Bey encounters only an unpromising unanimity of taste and opinion, then he assumes he will surely encounter dissent and division on visiting a political caucus. To the contrary, he reports, "I was surprised to find all the speakers coincide in their opinions" (Knapp 41).

But when it comes to the religious climate in America, the American people seem to him as fractious as they were elsewhere univocal, and he arrives at the conclusion that religious schisms extend through the country: "Scarcely a week passes but the belligerent parties assail each other from the press or pulpit, The state 
of irritation produced by this warfare can be easily [sic] imagined. And a change that will restore harmony is doubtless considered a desideratum by all sober and reflecting spectators" (125). To this stranger, it seems as if conflicting views of the many Christian sects that flourish in America put national unity outside the realm of possibility. But if Ali Bey imagines that conversion to Islam will "restore [the] harmony" that "is doubtless considered a desideratum by all," he is mistaken. There is no such univocality to be restored. Contrary to the situation in Spain and Algiers, the American "press or pulpit" has created forums that attract even the most divisive arguments. In tacitly agreeing to disagree, those who participate have agreed to tolerate one another's right to avail themselves of this forum, which thus offers a mechanism for dispersing any position that begins to take over.

To show how the early American novel does much the same thing at the level of social relationships, let us call attention to the first volume of Royall Tyler's Algerine Captive (1797). Here, Tyler introduces the protagonist, Updike Underhill, a physician in training with a genealogy both British and American. Despite the empty land that attracted so many people to America, this combination of features did not produce the farmer his father wanted him to be. Rather than develop the family holdings in property, ironically, Underhill lives out its legacy of migration until it is clear that his family no longer belongs anywhere in particular in the United States even though it is an unquestionably American family. So long as he wanders from region to region within the United States, Updike is at once hospitably received and barred from forming any relationships, personal or professional, that would let him belong to a community. When a schoolteacher, he finds his students mock rather than learn from him. When a physician, he discovers his patients prefer the nostrums of frauds and quacks. Because he is a New Englander, to his great disappointment, southern women steadfastly refuse his 
advances. Yet, as a ship's surgeon, he is recognized as an American and valued for his skill and unfailing good nature.

In 1799, Arthur Mervyn offered readers a novel organized by a sequence of ingeniously choreographed dispersals that summed up the formal moves of the earlier American fiction to which Brockden Brown pays homage. By 1836, Robert Montgomery Bird could turn this form inside out in Shepphard Lee and do within the phenomenological bubble of biographical experience what Mervyn did at the level of household and community. Bird's protagonist occupies one such bubble. Should Shepphard Lee encounter an obstacle, as happens with great regularity, the encounter is likely to separate his personal from his material property. This in turn releases his consciousness, thoughts, memories, tastes, physical abilities, and emotional inclinations into the category of virtual subjectivities, leaving what remains of his material property to the arbitrary rules governing the public domain. Much of it, including the body, becomes waste there for the taking. And so it remains - until another self stumbles upon those pieces and brings them to life as himself. Initially glad to become an individual by this rather absurd process, Sheppherd Lee invariably finds himself possessed by his body and attendant property and literally stumbles on the means of dispersing himself until he happens upon another available position to occupy.

The formation of successive versions of this single protagonist not only demonstrates that one man can actually become many; these recombinations of his personal and material property also render the novel's biographical narrative as a string of short stories. The account of each life breaks off from the previous account of Sheppherd Lee, as his story begins anew with a different constellation of personal and material assets, finally looping back again to settle into what had been Lee's inherited property, his body and patrimony. Once detached from his consciousness, however, they had been put into circulation. When he finally recovers that body and the land to which 
it entitles him, neither can consequently restore Shepphard Lee to the individual he once was - not that he wants to be that individual. It is their ability to shuck off and disperse their property that frees both Arthur Mervyn and Shepphard Lee to inhabit discarded clothes, discarded bodies, and the now unowned property once occupied by the bodies wearing those clothes. It is this ability, then, that identifies such protagonists as a perfect medium for forming social connections that reverse the logic of property.

If it requires a dispersal to set the protagonist in motion, always in pieces, then it takes a sequence of such dispersals to transform the framework within which he must become someone in relation to others. This seismic shift in the conditions for forming a community changes the rules by which early American novelists assembled a human figure that could serve as protagonist. ${ }^{10}$ To create such a figure out of the contents of the biographical form necessarily involved them in a project like that of the recombinatory art of bricolage. Although there is no critical consensus as to what specific aspects of the British novel they altered, classic accounts of the American novel invariably explain its Americanness as a compulsion to pit its own sense of good form against that maintained by the British prototype. ${ }^{11}$ We believe, to the contrary, that early American

10 In "Forms of Time and of the Chronotope in the Novel," Bakhtin proposes that "the image of man is always intrinsically chronotopic." That is to say, the image of man in literature is always the result and centerpiece of the spatialization of time specific to a historical moment. "In the literary artistic chronotope," he explains, "spatial and temporal indicators are fused into one carefully thought-out, concrete whole. Time, as it were, thickens, takes on flesh, becomes artistically visible; likewise, space becomes charged and responsive to the movements of time, plot and history" (84-85).

11 To describe what he calls "a native tradition," paradoxically, Richard Chase sees "this tradition, inevitably, as springing from England, but as differing from the tradition by its perpetual reassessment and reconstitution of romance within the novel form" (The American Novel, viii). Covering the American novel from 1789 to 1959, Leslie Fiedler sums up his effort as demonstrating "that the American novel has a character and fate different from the novel in France, Germany, even Russia" (Love and Death, 11). In a more recent account of the rise of the American novel, 
novelists must have had a more positive sense of what they were doing in order to create such very different protagonists who nevertheless - to a man or woman - exceeded the boundaries and leveled the internal hierarchies that characterized the British prototype. What were they after? What common sense of purpose prompted them to fashion novels that so dispersed persons and their property as to mount a direct challenge to Europe's fantasy of America as a wasteland awaiting appropriation?

\section{The Art of Statelessness}

In The Art of Not Being Governed, James C. Scott considers those inhabiting a national landscape dotted with "little nodes of hierarchy and power [that] were both unstable and geographically confined" as virtually stateless people. Given that most of its inhabits indeed lived outside the ambit of colonial government, much of North America would, in all likelihood, have struck the European as a periphery without a center. Scott would describe it "as a zone of refuge or 'shatter zone,' where the human shards of state formation and rivalry accumulated willy nilly" (Scott 7). If its inhabitants also saw it that way, then American novelists of that time could not have hoped to

Philip Gura also finds it necessary to distinguish the early American novel from the "narrative form imported from Europe" by virtue of the fact that the former provided an author with "a means for articulating her theological position and her prescriptions for her fellow citizens" (Truth's Ragged Edge, xii). Early on in The Dream of the Great American Novel, Lawrence Buell observes that "[a]nyone who cares about U.S. literature and culture has a natural interest in trying to understand what is distinctive about it" (10). Especially helpful for our purposes is Buell's demonstration, by means of an exhaustive survey of attempts to define the Great American Novel, that the idea of such a novel remains as inconclusive as it is tenacious. The definitional problem is not a function of the concept of "greatness" so much as a function of the assumption that novels are linked to nations, which prompts all these critics to define the American novel in negative terms, i.e., as one that is not British. Our own sampling shows that while most everyone agrees that American is not British fiction, no one can agree on why. 
make sense of their world in relation to some form of sovereignty - whether that of the federal government or of those opposed to the state's imposition on their individual sovereignty. To address the inhabitants of such a middle ground - natives, immigrants, refugees, outcasts, speculators, adventurers, military people - the early novel had to imagine ways of occupying this territory that did not prevent the flow of goods and people by subjecting them to a single form of domination. Judging by its proliferation during the period from the 1780 s through the 1820 s, the network novel apparently addressed the need to imagine community without one.

\section{Works cited}

Armstrong, Nancy, and Leonard Tennenhouse. "Novels Before Nations: How Early US Novels Imagined Community." A Special Issue, "Novels Beyond Nations." Ed. Jernej Jibjan. Canadian Review of Comparative Literature/ Revue Canadienne de Littérature Comparée 42.4 (Décembre 2015): 353-369. Print.

Bakhtin, Mikhail. "Forms of Time and of the Chronotope in the Novel." The Dialogic Imagination: Four Essays. Trans. Caryl Emerson and Michael Holquist. Austin: University of Texas Press, 1981, 84-258. Print.

Brackenridge, Hugh Henry. Modern Chivalry. Ed. Ed White. Indianapolis: Hackett Publishing Company, 2009. Print.

Buell, Lawrence. The Dream of the Great American Novel. Cambridge: Harvard University Press, 2014. Print.

Chase, Richard. The American Novel and Its Tradition. Baltimore: The Johns Hopkins University Press, 1957. Print.

Chavrat, William. Literary Publishing in America, 1790-1812. Amherst: University of Massachusetts Press, 1959. Print.

Dennie, Joseph. The Letters of Joseph Dennie, 1768-1812. Ed. Laura G. Pedder. Orono: University of Maine Press, 1936. Print.

Fiedler, Leslie. Love and Death in the American Novel. New York: Anchor Books, Doubleday, 1966. Print.

Green, James N. "The Rise of Book Publishing." Ed. Robert A. Gross and Mary Kelley. A History of the Book in America. Chapel Hill: University of North Carolina Press, 2010, II, 75-127. Print.

Gura, Philip F. Truth's Ragged Edge: The Rise of the American Novel. New York: Farrar, Strauss, and Giroux, 2013. Print. 
Kant, Immanuel. "To Perpetual Peace: A Philosophical Sketch." [1798] Perpetual Peace and Other Essays on Politics, History, and Morals. Trans. Ted Humphrey. Indianapolis: Hackett Publishing Company, 1983, 107-143. Print.

Knapp, Lorenzo Samuel. Extracts from a Journal of Travels in North America Consisting of Accounts of Boston and its Vicinity. Boston: Thomas Badger, 1818. Print.

Loughran, Trish. The Republic in Print: Print Culture in the Age of U.S. Nation Building, 1770-1870. New York: Columbia University Press, 2007. Print.

Lukács, George. Theory of the Novel: A Historico-Philosophical Essay on the Form of Great Epic Literature. Trans. Ana Bostock. Cambridge: MIT Press, 1971. Print.

Malthus, Thomas Robert. An Essay on the Principle of Population [1798]. Ed. Philip Appleman. New York: W.W. Norton, 2004. Print.

Markoe, Peter. The Algerine Spy in Pennsylvania or, Letters Written by a Native of Algiers on the Affairs of the United States in America from the Close of the Year 1783 to the Meeting of the Convention. Ed. Timothy Marr. Yardley, Pennsylvania: Westholme Publishing, 2008. Print.

Scott, James C. The Art of Not Being Governed: An Anarchist History of Upland Southeast Asia. New Haven: Yale University Press, 2009. Print.

Tennenouse, Leonard. The Importance of Feeling English in America: American Literature and the English Diaspora, 1750-1850. Princeton: Princeton University Press, 2007. Print.

Tölölyan, Khachig. "The Contemporary Discourse of Diaspora Studies." Comparative Studies of South Asia, Africa and the Middle East 27. 3 (2007): 647-655. Print.

Weiner, Annette B. Inalienable Possessions: The Paradox of Keeping While Giving. Berkeley: University of California Press, 1992. Print. 